\title{
Pollution plumes observed by aircraft over North China during the IPAC-NC field campaign
}

\author{
MA JianZhong ${ }^{1 *}, \underline{\text { WANG Wei }}^{2}$, LIU HongJie $^{2}$, CHEN Yue $^{1}$, XU XiaoBin $^{1} \&$ LELIEVELD Jos $^{3,4}$ \\ ${ }^{1}$ Chinese Academy of Meteorological Sciences, Beijing 100081, China; \\ ${ }^{2}$ Chinese Research Academy of Environmental Sciences, Beijing 100012, China; \\ ${ }^{3}$ Max Planck Institute for Chemistry, 55128 Mainz, Germany; \\ ${ }^{4}$ The Cyprus Institute, 1645 Nicosia, Cyprus
}

Received January 15, 2013; accepted May 21, 2013; published online July 16, 2013

\begin{abstract}
Strong pollution emissions from large urban and industrial centres in eastern China are thought to greatly impact regional air quality and global atmospheric chemistry. In this study, we investigate extensive pollution plumes over North China, observed by aircraft during the IPAC-NC (Influence of Pollution on Aerosols and Cloud Microphysics in North China) field campaign in spring 2006. Several pollution plumes were encountered, characterized by sharp and strong increases of $\mathrm{SO}_{2}$ and $\mathrm{NO}_{x}(\mathrm{NO}$ plus $\mathrm{NO}_{2}$ ) as well as remarkable $\mathrm{O}_{3}$ variability. During a flight performed downwind of the megacity Tianjin on 9 April, $\mathrm{O}_{3}$ was found to be depleted at $\mathrm{NO}_{x}>15 \mathrm{ppbv}$ and enhanced at $\mathrm{NO}_{x}$ mixing ratios of 6-7 ppbv. Our analysis indicates that the plumes had recently been released by industrial plants, and partly mixed with urban emissions, giving rise to the large-scale transport of air pollution and substantial degradation of air quality.
\end{abstract}

pollutant emissions, urban/industrial plumes, photochemical smog, tropospheric ozone, aircraft measurements

Citation: $\quad$ Ma J Z, Wang W, Liu H J, et al. Pollution plumes observed by aircraft over North China during the IPAC-NC field campaign. Chin Sci Bull, 2013, 58: 4329-4336, doi: 10.1007/s11434-013-5978-9

Pollutants freshly emitted from major urban and industrial centres, including e.g. power plants and petrochemical facilities, tend to undergo substantial chemical evolution during plume transport $[1,2]$. The chemical characteristics of pollution plumes and their variation as a function of transport distance are diverse, depending on the type and strength of emission sources, chemical features of the background atmosphere and meteorological conditions. Understanding the intricate physical, chemical and dynamical processes occurring in pollution plumes is essential to assess the influence of pollution outflow from megacities on air quality and climate from local to global scales [3-6]. Aircraft measurements can be very helpful in providing three-dimensional spatial and temporal insights into the transport and chemical evolution of pollution plumes [7-11]. The $\mathrm{O}_{3}$ variability, in combination with other reactive species in the plumes, has

*Corresponding author (email: mjz@cams.cma.gov.cn) been a main focus of many studies that investigated the non-linear response of ozone to its precursors and its influence on tropospheric chemistry. For example, pollution plumes are typically found to shift from being $\mathrm{O}_{3}$-depleted to $\mathrm{O}_{3}$-enriched during transport, and differences of a factor of 2 or more in ozone formation rates and yields as a function of $\mathrm{NO}_{x}\left(\equiv \mathrm{NO}+\mathrm{NO}_{2}\right)$ and volatile organic compound (VOC) concentrations were often observed in U.S. power plant plumes [1].

North China (namely Huabei in Chinese Pinyin), located between $32^{\circ}-42^{\circ} \mathrm{N}$ in eastern China, encompasses two megacities (Beijing and Tianjin) and several major industrial centres (e.g. Tangshan, Shijiazhuang and Taiyuan cities), which therefore represents a main pollution hot spot in China [12]. Satellite observations have shown an increasing trend in tropospheric $\mathrm{NO}_{2}$ and $\mathrm{O}_{3}$ over North China in the past decade [13-16]. Outflow of the emissions from North China, together with that of other severely polluted regions 
of eastern China, may have large impacts on background levels of pollutants over the Pacific Rim region, North America and even Europe [17-20]. Therefore, it is important to study the chemical characteristics of pollution plumes freshly emitted from urban and industrial centres in North China, not only to support the control of regional air pollution, but also for the understanding of tropospheric chemistry in the entire northern hemisphere. Recent studies based on surface measurements have shown that pollutants emitted from these urban and industrial centres can greatly impact air quality in the region [21-26]. However, measurements of pollution plumes aloft over North China have not yet been reported; though the levels and vertical distributions of air pollutants over this region were reported previously [27-30].

Here we present the results of comprehensive aircraft observations of pollution plumes over North China during the IPAC-NC (Influence of Pollution on Aerosols and Cloud Microphysics in North China) campaign in spring 2006. The IPAC-NC campaign was the first intensive field experiment that included simultaneous measurements of atmospheric trace gases, aerosols and clouds by aircraft over this part of China. The most important findings of IPAC-NC include the following. (1) Widespread haze clouds, characterized by very high concentrations of gaseous pollutants and haze particles mixed with low clouds, were observed, and it has been demonstrated that these haze-clouds exert a strong cooling forcing on regional climate [31]. (2)
Enhanced levels of $\mathrm{OH}$ and $\mathrm{HO}_{2}$ radicals were shown to be associated with the very high pollution concentrations, and it was indicated that the lower atmosphere over North China acts as a pollution and oxidation pool over China [29]. In this study, we focus on pollution plumes observed during the IPAC-NC campaign. We investigate some of the high levels and the variability of the reactive gases $\mathrm{SO}_{2}, \mathrm{NO}$, $\mathrm{NO}_{x}$ and $\mathrm{O}_{3}$ as well as $\mathrm{CO}$ and non-methane hydrocarbons (NMHCs) in pollution plumes encountered over North China. Potential sources and aging processes of the plumes and implications for regional chemistry are discussed.

\section{IPAC-NC field campaign}

The IPAC-NC field campaign was carried out between 2 April and 16 May, 2006, with a twin-engine YUN-12 aircraft operated from Tianjin International Airport. During the campaign, aircraft measurements were performed in the larger Beijing, Tianjin and Tangshan area with some flight tracks extending towards the Bohai Gulf. Figure 1 presents the spatial distributions of emission sources of the primary air pollutants $\mathrm{SO}_{2}, \mathrm{NO}_{x}, \mathrm{CO}$ and $\mathrm{NMHCs}$ from central North China, based on an emission inventory developed by our group [32]. The major emission centers coincide with megacities (Beijing $39.92^{\circ} \mathrm{N}, 116.46^{\circ} \mathrm{E}$ and Tianjin $39.02^{\circ} \mathrm{N}$, $117.02^{\circ} \mathrm{E}$ ) and other large industrial centers (Tangshan (a)

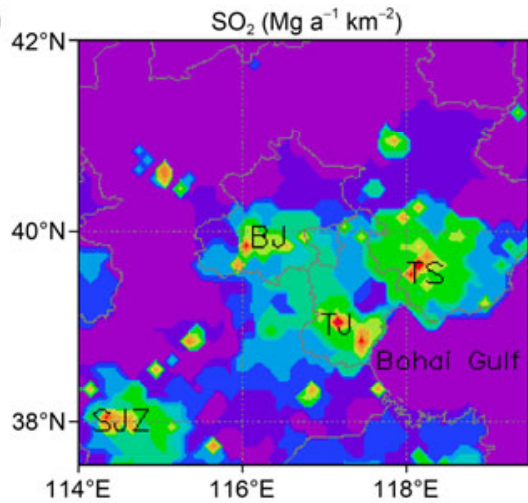

(c)

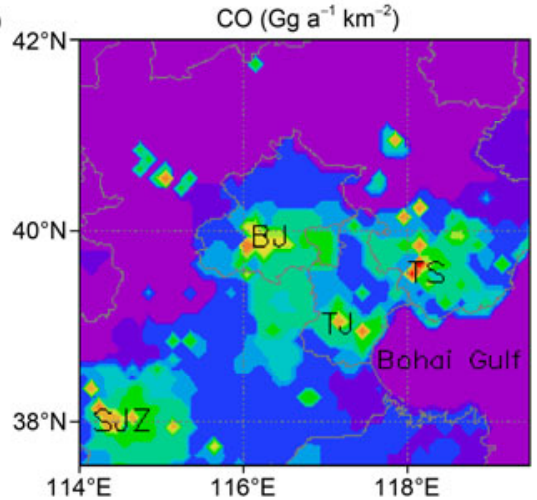

(b)

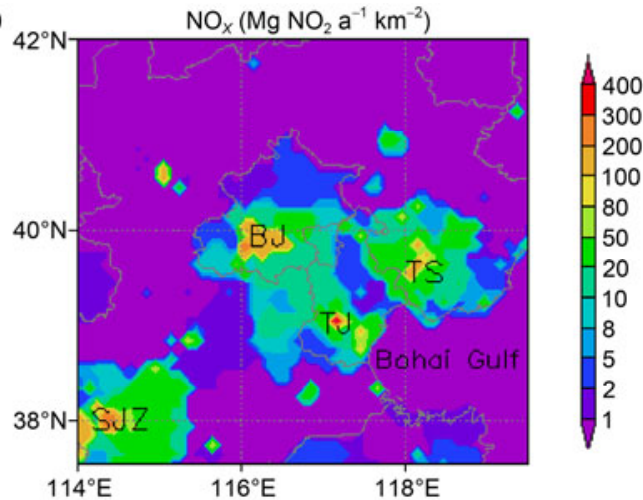

(d)

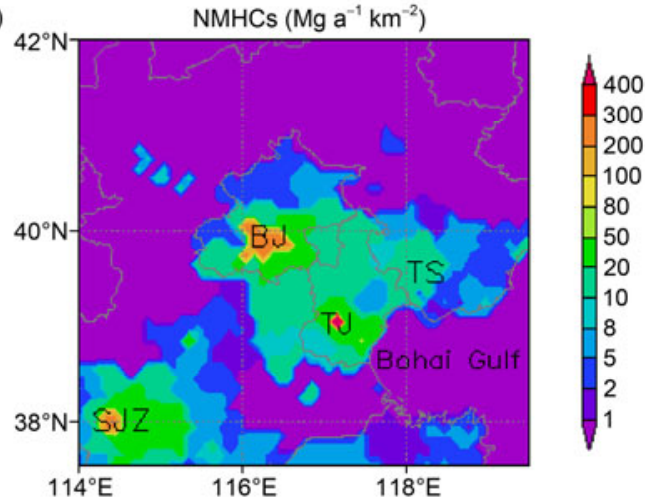

Figure 1 Annual emission rates of the primary pollutants (a) $\mathrm{SO}_{2}$, (b) $\mathrm{NO}_{x}$, (c) $\mathrm{CO}$ and (d) NMHCs in the central North China. Strong emissions from Beijing (BJ), Tianjin (TJ), Tangshan (TS) and Shijiazhuang (SJZ) cities are clearly visible. 
$39.36^{\circ} \mathrm{N}, 118.11^{\circ} \mathrm{E}$, Shijiazhuang $\left.38.02^{\circ} \mathrm{N}, 114.30^{\circ} \mathrm{E}\right)$. The strong air pollution emissions, plus the converging wind flow pattern, tend to result in the accumulation of pollutants in the lower atmosphere over the region [29].

Instruments for chemistry measurements were mounted on board the aircraft to detect the trace gases $\mathrm{SO}_{2}, \mathrm{NO}, \mathrm{NO}_{x}$, $\mathrm{O}_{3}$ and $\mathrm{CO}[29,31,33]$. A FEP-Teflon tube was used to introduce the ambient air from below the fuselage into the aircraft cabin for gas analysis. $\mathrm{SO}_{2}$ was monitored by a UV pulse fluorescence analyzer (TECO Model 43C-TL, USA) with a response time of about $80 \mathrm{~s}$. Nitrogen oxides were monitored by a chemiluminescence NO-NO $\mathrm{N}_{x}$ analyzer (TECO Model 42C-TL, USA). The analyzer measures the chemiluminescence of $\mathrm{NO}_{2}$ formed by the reaction between $\mathrm{NO}$ and $\mathrm{O}_{3}$, of which the intensity is proportional to the NO concentration. $\mathrm{NO}_{x}$ measurements are approximated using the thermal reduction of $\mathrm{NO}_{2}$ to $\mathrm{NO}$ by a heated $\left(320^{\circ} \mathrm{C}\right)$ molybdenum converter. Although it is expected that the signal of $\mathrm{NO}_{2}$ was dominant, other reactive nitrogen $\left(\mathrm{NO}_{y}\right)$ compounds may be converted to $\mathrm{NO}$ by this system so that the $\mathrm{NO}_{2}$ data presented here should be considered as an upper limit. The 10s duty cycle of the TE42C-TL alternates between $\mathrm{NO}$ and $\mathrm{NO}_{x}$ measurements. The difference between the two measurements allows the quasi-continuous signals of $\mathrm{NO}$ and $\mathrm{NO}_{x}$. Data were produced at $1 \mathrm{~Hz}$, although the readings of $\mathrm{NO}$ and $\mathrm{NO}_{x}$ were only updated every $10 \mathrm{~s} . \mathrm{O}_{3}$ was measured by a UV-absorption analyzer (TECO Model 49, USA) with a response time of $20 \mathrm{~s}$. CO was monitored by a gas filter correlation analyzer (TECO Model $48 \mathrm{C}$, USA) with a response time of about $60 \mathrm{~s}$. Since the $\mathrm{CO}$ analyzer on board the aircraft needed a relatively long period for stabilization during each flight, only part of the $\mathrm{CO}$ data could be used for analyses. NMHC sampling was done using 2-4 canisters per flight and each canister was typically filled in 10-20 min.

Seventeen research flights were performed during the IPAC-NC campaign [29]. Flight patterns were designed and implemented based on a combination of research objectives, weather conditions, and air traffic control regulations. The flight altitude ranged up to $3500 \mathrm{~m}$, the cruising velocity was generally $\sim 200 \mathrm{~km} \mathrm{~h}^{-1}$, and the flight duration was typically around $4-5 \mathrm{~h}$. Detailed descriptions of the IPAC-NC campaign, including the instruments, aircraft flight information and weather conditions, can be found in [29].

\section{Results and discussion}

\subsection{General features of the plumes}

Several pollution plumes, characterized by a sharp increase in mixing ratios of the primary pollutants $\mathrm{SO}_{2}$ and $\mathrm{NO}_{x}$ as well as remarkable $\mathrm{O}_{3}$ variability (enhanced or depleted) during extended flight tracks $(>10 \mathrm{~km})$, were encountered during IPAC-NC. The geographical positions of typical plumes, as observed on 9 April, 15 April and 7 May of 2006, are depicted in Figure 2. Also shown in Figure 2 are the wind fields and spatial tracer distributions over the region concurrent with the plume observations, which were simulated by the regional meteorological forecast model GRAPES with passive tracers added $[29,34,35]$. To show the regional transport of urban plumes, the tracers were released in the lowest layer of the model from the locations of the five major cities Beijing, Tianjin, Tangshan, Shijiazhuang and Taiyuan [29].

According to our model results, the plumes observed on 9 April had been directly influenced by the emissions from the Tianjin megacity. However, the plumes on 15 April and 7 May were not predicted by our urban tracer calculations, indicating that they had originated from other pollution sources than the cities included. Detailed features of the plumes observed by aircraft on these days are discussed below.

On 9 April, the airplane took off from Tianjin Airport at 01:54 UTC (09:54 Beijing Time), flew towards the north, and reached Huangzhuang Village $\left(39.48^{\circ} \mathrm{N}, 117.52^{\circ} \mathrm{E}\right)$ near northern Tianjin at about 02:18 UTC. Over Huangzhuang it performed several consecutive circle flights from the top downward until 05:35 UTC, with a radius of $15 \mathrm{~km}$ at the altitudes of $2.9,2.5,2.1,1.7,1.2,0.8$, and $0.4 \mathrm{~km}$, respectively. Aircraft measurements as well as satellite observations showed that widespread warm stratiform clouds prevailed over much of North China during the flight, covering an altitude range of about 750-1200 m [31]. Figure 3(a) shows the vertical profiles of $\mathrm{SO}_{2}, \mathrm{NO}, \mathrm{NO}_{x}$, and $\mathrm{O}_{3}$ measured during the circle flights on 9 April. Two pollution plumes were encountered, one above the clouds at an altitude of $1.7 \mathrm{~km}$, and another below the clouds at $0.4 \mathrm{~km}$.

On 15 April, when the weather was clear, a flight was performed at night, from 11:51 UTC to 14:43 UTC. The airplane flew across the Bohai Gulf, cruising from Gujuzi $\left(38.02^{\circ} \mathrm{N}, 118.37^{\circ} \mathrm{E}\right)$ to Haitiancun $\left(39.28^{\circ} \mathrm{N}, 119.03^{\circ} \mathrm{E}\right)$ at a constant altitude of $2 \mathrm{~km}$ and returning back to Gujuzi at a constant altitude of $1 \mathrm{~km}$. A pollution plume was observed when the airplane was approaching Gujuzi. On 7 May, also a clear day, the airplane took off from Tianjin Airport at 04:45 UTC, flew towards the east, and reached the border area between Tianjin Municipality and Hebei Province $\left(39.08^{\circ} \mathrm{N}, 118.07^{\circ} \mathrm{E}\right.$, south of Tangshan City) at about 05:20 UTC. There, it performed sequential vertical cross section flights from the flight top downward until 06:33 UTC, with a horizontal width of about $60 \mathrm{~km}$ at altitudes of 2.6, 2.1, $1.6,1.1$, and $0.6 \mathrm{~km}$. As shown in Figure 3(b), a plume was observed at an altitude of $0.6 \mathrm{~km}$. It appears that the vertical extent of the plumes on these days was limited to less than $\sim 500 \mathrm{~m}$ depth.

\section{2 $\mathrm{SO}_{2}$ and $\mathrm{NO}_{x}$ in the plumes}

Figure 4 shows the changes in gaseous pollutant concentrations as a function of flight time in the plumes observed on 

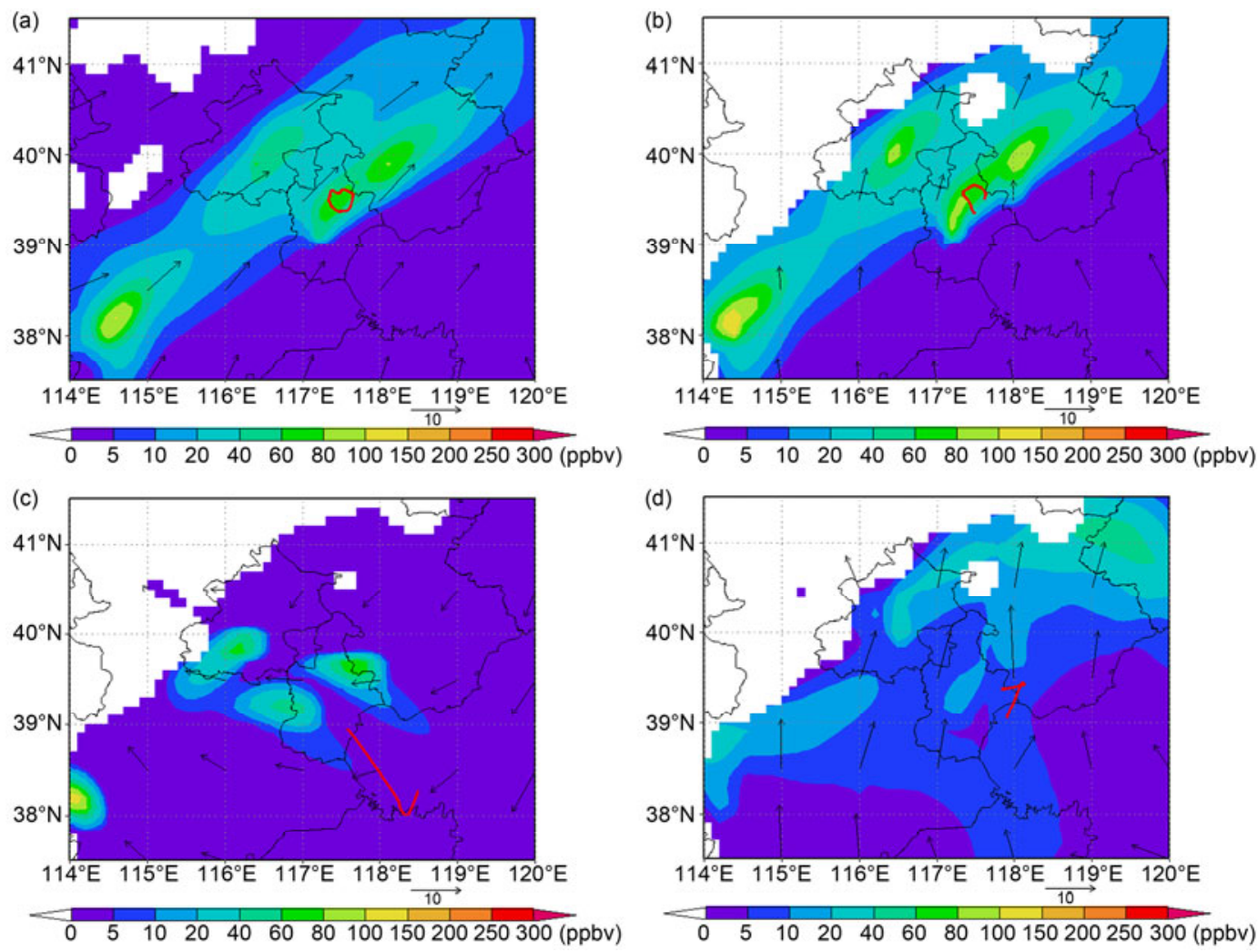

Figure 2 Geographical locations (red lines) of the plumes observed during flights and coincident wind fields and spatial distributions of pollution tracers emitted from major urban centers of North China, as simulated by the model for (a) $850 \mathrm{hPa}$ on 9 April, 2006; (b) $925 \mathrm{hPa}$ on 9 April, 2006; (c) $925 \mathrm{hPa}$ on 15 April, 2006; (d) $925 \mathrm{hPa}$ on 7 May, 2006. Mountainous areas are masked (white).
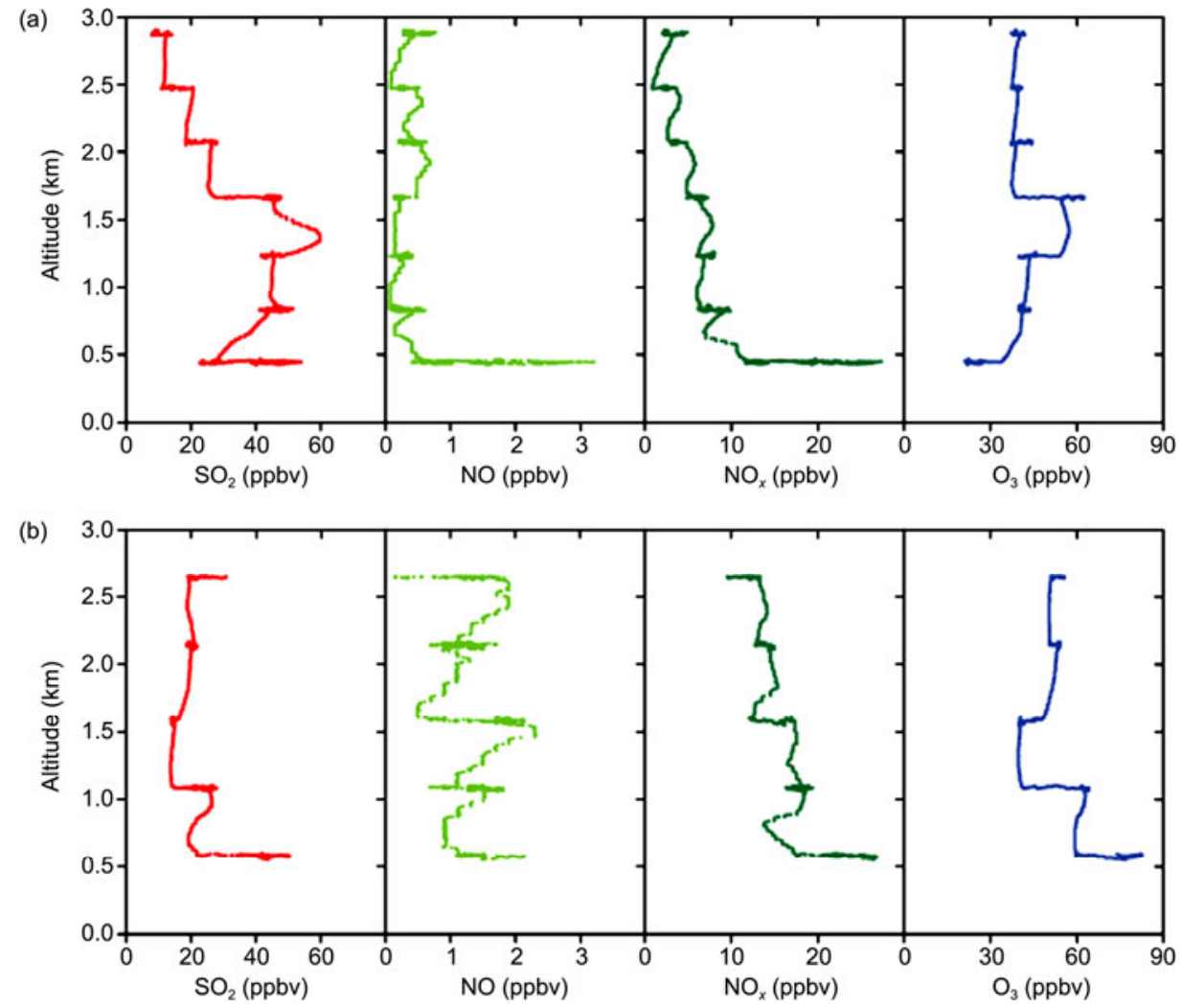

Figure 3 Vertical profiles of trace gases around the time when the plumes were observed on 9 April, 2006 (a) and 7 May, 2006 (b). 

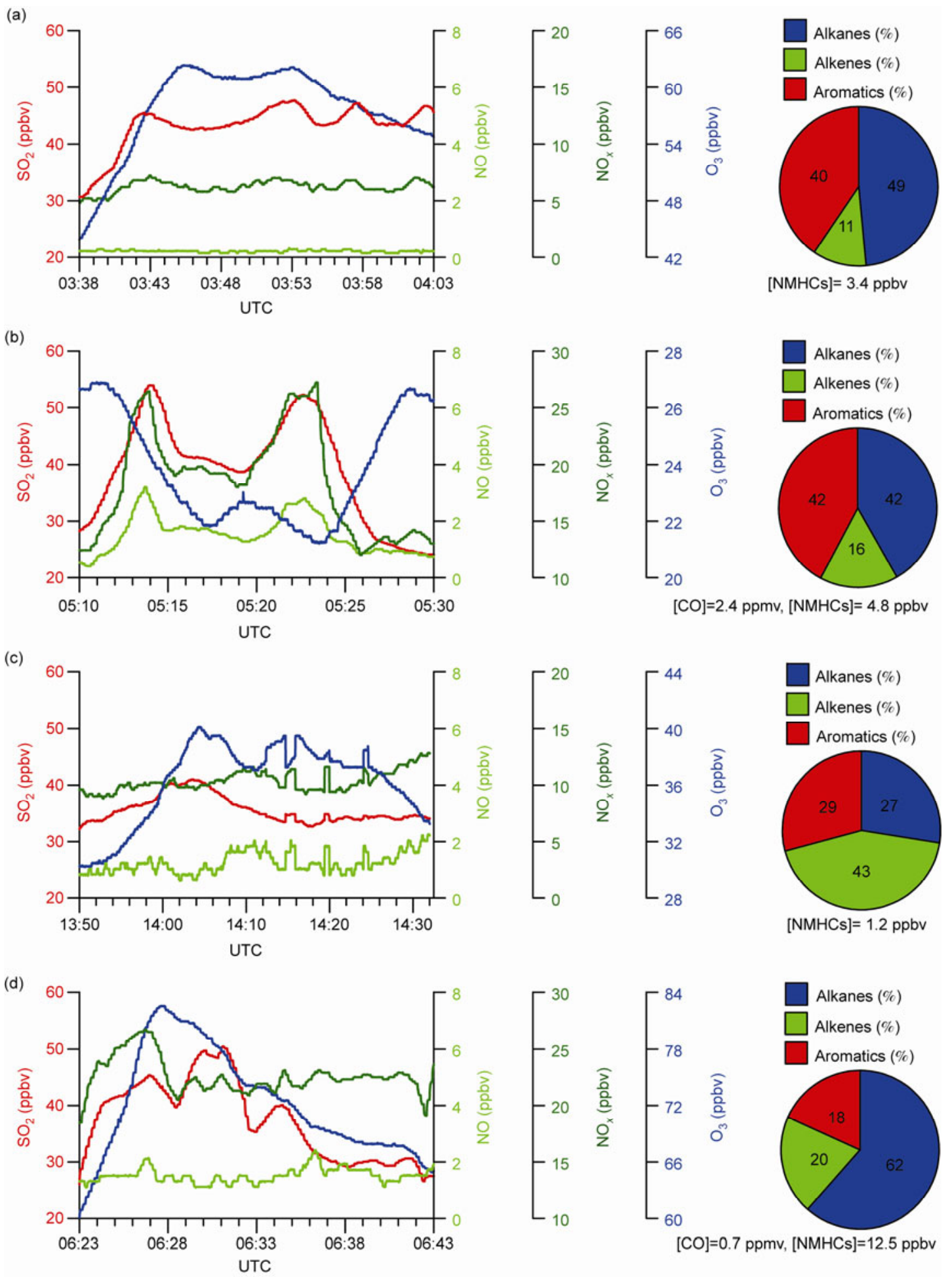

Figure 4 Changes in mixing ratios of $\mathrm{SO}_{2}, \mathrm{NO}, \mathrm{NO}_{x}$, and $\mathrm{O}_{3}$ as a function of flight time in the plumes, as observed at (a) $1.7 \mathrm{~km}$ altitude on 9 April, 2006 , (b) $0.4 \mathrm{~km}$ altitude on 9 April, 2006, (c) $1.0 \mathrm{~km}$ altitude on 15 April, 2006 and (d) $0.6 \mathrm{~km}$ altitude on 7 May, 2006. Also shown are NMHC mixing ratios and the compound categories as well as the peak CO mixing ratios (available only for cases (b) and (d)).

9 April, 15 April and 7 May, 2006. Remarkably higher primary gaseous pollutants were observed persistently for flight times of 10-20 min (33-66 km along the flight track), characterizing the extent of the plumes. For example, the mixing ratio of $\mathrm{SO}_{2}$ reached up to $41-54 \mathrm{ppbv}$ in the plume cores, 10-20 ppbv higher than outside the plumes. The mixing ratio of $\mathrm{NO}_{x}$ in the plumes was up to 7-27 ppbv, about 2-10 ppbv higher than outside the plumes. CO data were missing for some plumes due to instrumental limitations. Nevertheless, a peak value of 2.4 ppmv for $\mathrm{CO}$ was observed 
in the $0.4 \mathrm{~km}$ altitude plume of 9 April, $0.8-1.0$ ppmv higher than in the adjacent air masses.

The concentrations of primary pollutants in a plume are affected by various processes, including dispersion, mixing and chemical reactions. Dispersion is expected to have the same impact on all pollutants in a plume. The effects of mixing processes depend on the concentrations of pollutants in the plume relative to those in the ambient atmosphere as well as in other plumes. The influence of chemical reactions is typically different for the various species in the plumes. Therefore, the relative changes of the mixing ratios of primary pollutants with different chemical lifetimes can be used as an indicator of the plume aging process. The lifetimes of $\mathrm{SO}_{2}$ and $\mathrm{NO}_{x}$ against gas-phase oxidation by $\mathrm{OH}$ in the planetary boundary layer of North China are estimated to be about a day and $4 \mathrm{~h}$, respectively, based on our box model simulations constrained by measurements during IPAC-NC [29]. Therefore, it can be expected that with constant emissions the $\mathrm{SO}_{2} / \mathrm{NO}_{x}$ ratio increases with plume age, assuming that no mixing occurred.

Table 1 shows the molar ratios of the primary pollutants measured in the plume cores by our aircraft, as well as those emitted from various pollution sources, according to the emission inventory for North China [32]. The $\mathrm{SO}_{2} / \mathrm{NO}_{x}$ ratios were measured to be $\sim 2.0 \mathrm{ppbv} / \mathrm{ppbv}$ in the $0.4 \mathrm{~km}$ altitude plume of 9 April and $\sim 1.8 \mathrm{ppbv} / \mathrm{ppbv}$ in the $0.6 \mathrm{~km}$ altitude plume of 7 May, comparable to the emission ratios for power generation and industrial activities; they were $\sim 3.2$ ppbv/ppbv in the $1.0 \mathrm{~km}$-altitude night-time plume of 15 April and $\sim 7.3 \mathrm{ppbv} / \mathrm{ppbv}$ in the $1.7 \mathrm{~km}$ altitude plume of 9 April, remarkably larger than the emission ratios for power generation and industrial activities. The $\mathrm{SO}_{2} / \mathrm{NO}_{x}$ ratios measured in the plumes were much higher than the emission ratios for traffic and biomass burning. This indicates that the observed plumes had recently originated from power gener-

Table 1 Molar ratios of the primary pollutants $\mathrm{SO}_{2}$ and $\mathrm{NO}_{x}$, based on an emission inventory for North China [32] and aircraft measurements in the plume cores during the IPAC-NC field campaign

$\mathrm{SO}_{2} / \mathrm{NO}_{x}(\mathrm{ppbv} / \mathrm{ppbv})$

\begin{tabular}{ll}
\hline Emissions & 1.6 \\
Power generation & 2.0 \\
Industrial activities & 0.1 \\
Traffic & 0.3 \\
Biomass burning & 0.3 \\
Beijing megacity & 1.0 \\
Tianjin megacity & \\
Plumes & 7.3 \\
9 April 2006 (1.7 km altitude $)$ & 2.0 \\
9 April $2006(0.4 \mathrm{~km}$ altitude $)$ & 3.2 \\
15 April $2006(1.0 \mathrm{~km}$ altitude $)$ & 1.8 \\
7 May $2006(0.6 \mathrm{~km}$ altitude $)$ & \\
\hline
\end{tabular}

Ation and/or industrial plants, though the influence of emissions from traffic and biomass burning (especially $\mathrm{NO}_{x}$ ) on the plumes cannot be excluded. Zhou et al. [11] showed that within a limited range of plume ages $(0.3-1.3 \mathrm{~h})$, the $\mathrm{SO}_{2} /$ $\mathrm{NO}_{x}$ ratios measured in the Texas power plant plumes (which varied between 1.2 and $11 \mathrm{ppbv} / \mathrm{ppbv}$ ) were predominantly determined by the emission ratios of the corresponding plants (which varied between 1.1 and $8.9 \mathrm{ppbv} /$ ppbv). The plumes that we observed most likely originated from different plants, with $\mathrm{SO}_{2} / \mathrm{NO}_{x}$ emission ratios smaller or larger than the average emission ratios shown in Table 1. Therefore, the ages of these plumes cannot be inferred exactly by merely using measured $\mathrm{SO}_{2} / \mathrm{NO}_{x}$ ratios in a plume without detailed information of individual emission sources.

\section{$2.3 \mathrm{O}_{3}$ in the plumes}

The variability of the secondary photochemical pollutant $\mathrm{O}_{3}$ was large in the different plumes, acting either divergent from (Figure 4(b)) or in parallel (Figure 4(a), (c) and (d)) to that of its precursors. For example, the $\mathrm{O}_{3}$ mixing ratio was depleted by $\sim 5$ ppbv in the $0.4 \mathrm{~km}$ altitude plume of 9 April at $\mathrm{NO}_{x}>15 \mathrm{ppbv}(\mathrm{NO}>2 \mathrm{ppbv}$ ) (Figure 4(b)), but was enhanced by up to $\sim 20 \mathrm{ppbv}$ in the $1.7 \mathrm{~km}$ altitude plume on the same day at $\mathrm{NO}_{x}$ mixing ratios of $6-7 \mathrm{ppbv}(\mathrm{NO} \approx 0.5$ ppbv) (Figure 4(a)). An increase of $\mathrm{O}_{3}$ by up to $\sim 10 \mathrm{ppbv}$ was also found in the night-time plume of 15 April, at an $\mathrm{NO}_{x}$ level of $10-12 \mathrm{ppbv}(\mathrm{NO} \approx 1-2$ ppbv) (Figure 4(c)). Note that $\mathrm{CO}$ as well as total NMHCs and their composition contributions also varied greatly from one plume to another. Ozone production is often nonlinear with respect to its precursors [36], being confirmed by numerous field experiments including aircraft measurements of urban and industrial plumes [1,37-39]. Ryerson et al. [1] reported that at 36 $\mathrm{km}$ downwind of a power plant in the United States, $\mathrm{O}_{3}$ concentrations were enhanced at $\mathrm{NO}_{x}<10$ ppbv toward the edge of the plume, whereas $\mathrm{O}_{3}$ was still suppressed through titration by $\mathrm{NO}$ at $\mathrm{NO}_{x}>15$ ppbv within the plume core. During IPAC-NC, the $\mathrm{O}_{3}$ mixing ratio was enhanced by up to $\sim 20 \mathrm{ppbv}$ in the $0.6 \mathrm{~km}$ altitude plume of 7 May at $\mathrm{NO}_{x}>$ 20 ppbv (Figure 4(d)), in contrast to the cases above. This can be explained by the addition of freshly emitted $\mathrm{NO}_{x}$ to an aged plume. In such a plume, ozone formation probably occurred for some time and the accumulated $\mathrm{O}_{3}$ can then be titrated by freshly released NO. As a result, the observed decrease of $\mathrm{O}_{3}$ is not significant and the level of NO was not very high $(<2 \mathrm{ppbv})$ in the plume. It is interesting to see that for the daytime observations in IPAC-NC, ozone mixing ratios in the plumes could reach $60-80 \mathrm{ppbv}$ in the $\mathrm{O}_{3}$-enhancement cases (Figure 4(a) and (d)), much higher than the 21-25 ppbv in the $\mathrm{O}_{3}$-depletion case (Figure 4(b)). Such differences between the pollution plumes can significantly influence the $\mathrm{O}_{3}$ distributions at regional scales.

$\mathrm{O}_{3}$ in the plumes can be changed by two types of chemical mechanisms, the titration by NO, which does not change 
the amount of total oxidant $\mathrm{O}_{x}$, and the net production (destruction) of $\mathrm{O}_{3}$, which results in an increase (decrease) of $\mathrm{O}_{x}$. We calculated $\mathrm{O}_{x}$ using measured $\mathrm{O}_{3}$, NO and $\mathrm{NO}_{x}$ assuming $\left[\mathrm{NO}_{2}\right]=\left[\mathrm{NO}_{x}\right]-[\mathrm{NO}]$, though detected $\mathrm{NO}_{x}$ might probably include some other $\mathrm{NO}_{y}$ compounds [29]. It turns out that $\mathrm{O}_{x}$ concentrations are higher within the plumes than outside in all cases (not shown in the figure) and they covary with $\mathrm{NO}_{x}$ in the $\mathrm{O}_{3}$ depletion cases (Figure 4(b)) while the correlation is much less in the $\mathrm{O}_{3}$ enhancement cases (Figure 4(a), (c) and (d)). Higher plume $\mathrm{O}_{x}$ in the $\mathrm{O}_{3}$ depletion case is accompanied with enhanced $\mathrm{NO}_{2}$ resulting from the titration of $\mathrm{O}_{3}$ by $\mathrm{NO}$ within the plume; however, it cannot be quantitatively determined to what extent photochemical source and sink processes played a role due to limited measurement data.

For comparison, net $\mathrm{O}_{3}$ destruction was observed in an urban plume (from Manaus) over the heart of Amazon Basin as reported by Kuhn et al. [39]. Under high $\mathrm{NO}_{2}$ conditions in the plumes, depletion of $\mathrm{OH}$ radicals, needed for NMHC oxidation, may occur, resulting in the decreased availability of peroxy radicals for $\mathrm{O}_{3}$ production. Higher $\mathrm{O}_{x}$ in the $\mathrm{O}_{3}$ enhancement case indicates net photochemical $\mathrm{O}_{3}$ production in the plume during the sampling period or earlier. In North China there are many large industrial complexes with power plants, steel and iron smelters, cement factories and chemical plants, i.e. upwind of the area of investigation [32]. The mix of gaseous pollutants, especially NMHCs, emitted from these various industrial sectors can be very diverse, as indicated by the fractional contributions of alkanes, alkenes and aromatics to the total NMHCs measured in the plumes, with sometimes very high mixing ratios in excess of $12 \mathrm{ppbv}$ (Figure 4). Plumes from these pollution sources could be merged and mixed into air masses or plumes transported from urban areas such as Tianjin, which hitherto photochemically aged with enhanced $\mathrm{O}_{3}$ concentrations. Therefore, the plumes encountered by our instrumented aircraft during IPAC-NC represent a wide diversity of chemical characteristics.

\section{Conclusions}

Several pollution plumes were observed by aircraft over North China during the IPAC-NC field campaign in spring 2006. The spatial scales of these plumes were typically limited to less than $500 \mathrm{~m}$ depth and 30-60 km width. While we typically found sharp increases in $\mathrm{SO}_{2}$ and $\mathrm{NO}_{x}$, remarkable $\mathrm{O}_{3}$ variability (either relative increases or decreases) were also observed in the plumes. The mixing ratios of $\mathrm{SO}_{2}$ reached up to $\sim 50 \mathrm{ppbv}$ in the plumes, with increases of $\sim 20 \mathrm{ppbv}$ relative to the plume environmental air. The peak mixing ratio of $\mathrm{NO}_{x}$ in the plumes was observed to be nearly $30 \mathrm{ppbv}$, about $10 \mathrm{ppbv}$ higher than outside the plumes. For a similar vertical profile downwind of the megacity Tianjin on 9 April, $\mathrm{O}_{3}$ was found to be depleted at
$\mathrm{NO}_{x}>15$ ppbv in the $0.4 \mathrm{~km}$ altitude plume and enhanced at $\mathrm{NO}_{x}$ mixing ratios of 6-7 ppbv in the $1.7 \mathrm{~km}$ altitude plume. While the decrease of $\mathrm{O}_{3}$ in the plume can at least partly be attributed to the titration of $\mathrm{O}_{3}$ by $\mathrm{NO}$, the enhancement of $\mathrm{O}_{3}$ in the plumes indicates net photochemical production of $\mathrm{O}_{3}$, with $\mathrm{O}_{3}$ mixing ratios in the plumes reaching 60-80 ppbv. The molar ratios of $\mathrm{SO}_{2}$ to $\mathrm{NO}_{x}$ measured in the plumes were typically $\sim 2.0 \mathrm{ppbv} / \mathrm{ppbv}$, indicating that they had recently been emitted from power generation or industrial plants. Plumes from different pollution sources can merge and mix with plumes transported from urban areas. Further source identification and chemical characterization of the plumes in eastern China needs to be performed in dedicated studies with an extended suite of instrumentation.

This work was supported by the National Natural Science Foundation of China (40433008), the National Basic Research Program of China (2011CB706903), and the China Special Fund for Meteorological Research in the Public Interest (GYHY201206015). The research leading to these results has also received funding from the European Research Council under the European Union's Seventh Framework Programme (FP7/20072013)/ERC grant agreement no. 226144. We are grateful to Xu Mingzhi and Yin Baohui of CRAES and Wang Xiaobin of CAMS for their assistance with the aircraft measurements.

1 Ryerson T B, Trainer M, Holloway J S, et al. Observations of ozone formation in power plant pplumes and implications for ozone control strategies. Science, 2001, 292: 719-723

2 Brown S S, Ryerson T B, Wollny A G, et al. Variability in nocturnal nitrogen oxide processing and its role in regional air quality. Science, 2006, 311: 67-70

3 Lawrence M G, Butler T M, Steinkamp J, et al. Regional pollution potentials of megacities and other major population centers. Atmos Chem Phys, 2007, 7: 3969-3987

4 Molina L T, Madronich S, Gaffney J S, et al. An overview of the MILAGRO 2006 Campaign: Mexico City emissions and their transport and transformation. Atmos Chem Phys, 2010, 10: 8697-8760

5 Parrish D D, Allen D T, Bates T S, et al. Overview of the Second Texas Air Quality Study (TexAQS II) and the Gulf of Mexico Atmospheric Composition and Climate Study (GoMACCS). J Geophys Res, 2009, 114: D00F13

6 Singh H B, Brune W H, Crawford J H, et al. Chemistry and transport of pollution over the Gulf of Mexico and the Pacific: Spring 2006 INTEX-B campaign overview and first results. Atmos Chem Phys, 2009, 9: 2301-2318

7 Real E, Pisso I, Law K S, et al. Toward a novel high-resolution modeling approach for the study of chemical evolution of pollutant plumes during long-range transport. J Geophys Res, 2010, 115: D12302

8 Zaveri R A, Berkowitz C M, Brechtel F J, et al. Nighttime chemical evolution of aerosol and trace gases in a power plant plume: Implications for secondary organic nitrate and organosulfate aerosol formation, $\mathrm{NO}_{3}$ radical chemistry, and $\mathrm{N}_{2} \mathrm{O}_{5}$ heterogeneous hydrolysis. J Geophys Res, 2010, 115: D12304

9 Lee S H, Kim S W, Trainer M, et al. Modeling ozone plumes observed downwind of New York City over the North Atlantic Ocean during the ICARTT field campaign. Atmos Chem Phys, 2011, 11: 7375-7397

10 Brown S S, Dubé W P, Karamchandani $\mathrm{P}$, et al. Effects of $\mathrm{NO}_{x}$ control and plume mixing on nighttime chemical processing of plumes from coal-fired power plants. J Geophys Res, 2012, 117: D07304

11 Zhou W, Cohan D S, Pinder R W, et al. Observation and modeling of the evolution of Texas power plant plumes. Atmos Chem Phys, 2012, 
12: $455-468$

12 Ma J Z, Xu X B, Zhao C S, et al. A review of atmospheric chemistry research in China: Photochemical smog, haze pollution, and gasaerosol interactions. Adv Atmos Sci, 2012, 29: 1006-1026

13 Zhang X Y, Zhang P, Zhang Y, et al. The trend, seasonal cycle, and sources of tropospheric $\mathrm{NO}_{2}$ over China during 1997-2006 based on satellite measurement. Sci China Ser D-Earth Sci, 2007, 50: 1877-1884

14 Xu X, Lin W L. 1979-2005 trends of tropospheric ozone over China based on the satellite data (in Chinese). Adv Clim Change Res, 2010, 6: 100-105

15 Zhang Q, Geng G N, Wang S W, et al. Satellite remote sensing of changes in $\mathrm{NO}_{x}$ emissions over China during 1996-2010. Chin Sci Bull, 2012, 57: 2857-2864

16 Shen L L, Wang Y X. Changes in tropospheric ozone levels over the Three Representative Regions of China observed from space by the Tropospheric Emission Spectrometer (TES), 2005-2010. Chin Sci Bull, 2012, 57: 2865-2871

17 Zhang L, Jacob D J, Boersma K F, et al. Transpacific transport of ozone pollution and the effect of recent Asian emission increases on air quality in North America: An integrated analysis using satellite, aircraft, ozonesonde, and surface observations. Atmos Chem Phys, 2008, 8: 6117-6136

18 Cooper O R, Parrish D D, Stohl A, et al. Increasing springtime ozone mixing ratios in the free troposphere over western North America. Nature, 2010, 463: 344-348

19 Barletta B, Meinardi S, Simpson I J, et al. Characterization of volatile organic compounds (VOCs) in Asian and north American pollution plumes during INTEX-B: Identification of specific Chinese air mass tracers. Atmos Chem Phys, 2009, 9: 5371-5388

20 Fiedler V, Nau R, Ludmann S, et al. East Asian $\mathrm{SO}_{2}$ pollution plume over Europe-Part 1: Airborne trace gas measurements and source identification by particle dispersion model simulations. Atmos Chem Phys, 2009, 9: 4717-4728

21 Lin W, Xu X, Zhang X, et al. Contributions of pollutants from north china plain to surface ozone at the shangdianzi GAW station. Atmos Chem Phys, 2008, 8: 5889-5898

22 Lin $\mathrm{W}, \mathrm{Xu} \mathrm{X}, \mathrm{Ge} \mathrm{B}$, et al. Characteristics of gaseous pollutants at Gucheng, a rural site southwest of Beijing. J Geophys Res, 2009, 114: D00G14

23 Meng Z Y, Xu X B, Yan P, et al. Characteristics of trace gaseous pollutants at a regional background station in Northern China. Atmos Chem Phys, 2009, 9: 927-936

24 Wang T, Nie W, Gao J, et al. Air quality during the 2008 Beijing Olympics: Secondary pollutants and regional impact. Atmos Chem
Phys, 2010, 10: 7603-7615

$25 \mathrm{Xu} \mathrm{J}$, Ma J Z, Zhang X L, et al. Measurements of ozone and its precursors in Beijing during summertime: Impact of urban plumes on ozone pollution in downwind rural areas. Atmos Chem Phys, 2011, 11: $12241-12252$

26 Xu W Y, Zhao C S, Ran L, et al. Characteristics of pollutants and their correlation to meteorological conditions at a suburban site in the North China Plain. Atmos Chem Phys, 2011, 11: 4353-4369

27 Ding A J, Wang T, Thouret V, et al. Tropospheric ozone climatology over Beijing: Analysis of aircraft data from the MOZAIC program. Atmos Chem Phys, 2008, 8: 1-13

28 Chen Y, Zhao C, Zhang Q, et al. Aircraft study of Mountain Chimney Effect of Beijing, China. J Geophys Res, 2009, 114: D08306

29 Ma J Z, Wang W, Chen Y, et al. The IPAC-NC field campaign: A pollution and oxidization pool in the lower atmosphere over Huabei, China. Atmos Chem Phys, 2012, 12: 3883-3908

30 Li W, Shi Z, Zhang D, et al. Haze particles over a coal-burning region in the China Loess Plateau in winter: Three flight missions in December 2010. J Geophys Res, 2012, 117: D12306

31 Ma J Z, Chen Y, Wang W, et al. Strong air pollution causes widespread haze-clouds over China. J Geophys Res, 2010, 115: D18204

32 Zhao B, Wang P, Ma J Z, et al. A high-resolution emission inventory of primary pollutants for the Huabei region, China. Atmos Chem Phys, 2012, 12: 481-501

33 Wang W, Ma J, Hatakeyama S, et al. Aircraft measurements of vertical ultrafine particles profiles over Northern China coastal areas during dust storms in 2006. Atmos Environ, 2008, 42: 5715-5720

34 Chen D, Shen X. Recent progress on GRAPES research and application. Q J Appl Meteorol, 2006, 17: 773-777

35 Xue J S, Zhuang S Y, Zhu G F, et al. Scientific design and preliminary results of three-dimensional variational data assimilation system of GRAPES. Chin Sci Bull, 2008, 53: 3446-3457

36 Liu S, Trainer M, Fehsenfeld F, et al. Ozone production in the rural troposphere and the implications for regional and global ozone distributions. J Geophys Res, 1987, 92: 4191-4207

37 Kleinman L I, Daum P H, Imre D G, et al. Ozone production in the New York City urban plume. J Geophys Res, 2000, 105: 14495-14511

38 Zaveri R A, Berkowitz C M, Kleinman L I, et al. Ozone production efficiency and $\mathrm{NO}_{x}$ depletion in an urban plume: Interpretation of field observations and implications for evaluating $\mathrm{O}_{3}-\mathrm{NO}_{x}$-VOC sensitivity. J Geophys Res, 2003, 108: 4436

39 Kuhn U, Ganzeveld L, Thielmann A, et al. Impact of Manaus City on the Amazon Green Ocean atmosphere: Ozone production, precursor sensitivity and aerosol load. Atmos Chem Phys, 2010, 10: 9251-9282

Open Access This article is distributed under the terms of the Creative Commons Attribution License which permits any use, distribution, and reproduction in any medium, provided the original author(s) and source are credited. 